\title{
Chapter v
}

\section{Contesting caste identity}

\section{Literature and caste issues}

Caste is one of the dominant themes in Indonesian literature from Bali, and issues to do with caste recur in all literary genres including poetry, prose and drama. ${ }^{1}$ In the 1920 s and 1930s, caste was the foremost subject matter used in poetry, which was the most common genre during this period. During the national revolution period, caste based-themes continued to appear, but less frequently, because during this period Balinese writers, like those elsewhere in Indonesia, were concerned with more compelling issues such as the national revolution, poverty, morality, the leadership crisis, and national identity. Preoccupied with these national social and political issues, Balinese writers rarely wrote about local subjects such as caste.

However, during the New Order period, when the regime prohibited the use of the arts and literary works for social and political propaganda and particularly for criticism of itself, Balinese writers returned to exploring local issues, especially the impact of the development of tourism and the conflict between modernity and local customs, such as the caste system. Almost every Balinese writer has written about caste, which in the Reformation period is still a leading topic. It has been used by recent Balinese writers as a basis for short stories, novels and poetry written in Indonesian, and is also

1 The structure of the caste system in Bali and its terminology were outlined in Chapter II. For a detailed bibliography of short stories and plays discussed in this chapter, see Appendix F. 
a dominant topic in modern literature in the Balinese language. ${ }^{2}$ Reading works about this issue in either language helps provide an understanding of how the Balinese manage the ongoing tension between maintaining and opposing the traditional social hierarchy. It also highlights the deep flaws in the image of Balinese harmony so commonly featured in tourism promotion.

There are a number of reasons why Balinese writers continue to discuss caste. Since the first debates about this issue between Surya Kanta and Bali Adnjana in the 1920s, caste differences have remained one of the most significant controversies in Balinese public discourse. ${ }^{3}$ Caste disputes can begin as intellectual debates, but then extend into social conflicts, sometimes going so far as to involve destruction of property. This can result in substantial comment in regional newspapers. ${ }^{4}$ Given the ongoing caste conflict in public life, it is natural that Balinese writers have chosen to write about what is happening around. In addition, disputes between people of different castes provide a ready-made conflict formula for writers to access when creating a narrative structure, ${ }^{5}$ and Balinese writers are strongly motivated to write about caste because stories dealing with this topic receive encouraging responses from readers and publishers of Indonesian literature.

2 For a history of modern literature in the Balinese language and a discussion on themes regarding caste in this literature, see Putra 2000b.

$3 \quad$ Wiana and Santeri 1993; Pitana 1997, 1999a; Howe 1995, 2005; Schulte Nordholt 2007.

4 See P. Wirata 2007. The article comments on a caste-based conflict that involved a violent attack on a number of brahmana houses in Klungkung, East Bali, on the night of the Hindu Nyepi holiday, 19 March 2007. The attack was a continuation of a conflict that had begun two years earlier (2005) when 24 brahmana families declared their intention to resign from customary village membership and form their own exclusive customary village organization. See also 'Nyepi di Klungkung, rumah dilempari batu', Bali Post 21-3-2007 and 'Massa hancurkan puluhan rumah, tiga sepeda motor dibakar', Bali Post 22-3-2007.

5 Aryantha Soethama, interview, Denpasar, 15-12-1999. Aryantha Soethama published an article in the Bali Post in 1996 (which I have not been able to locate) in which he stresses his point that caste conflict is still an interesting subject for Balinese writers. He included three stories based on issues related to caste in his award winning short story collection Mandi api (2006), which are discussed here: Tembok puri (The palace wall), Bohong (Lies) and Sekarang dia bangsawan (He is an aristocrat now). 
Many works on caste conflict by Balinese writers have secured the attention of national publishers or have appeared in national newspapers, literary journals and popular women's magazines. The distinctive caste-based nature of works by Rasta Sindhu, Aryantha Soethama and Oka Rusmini has contributed to their winning national literary awards. These and other works having caste as their main theme expand the contribution Balinese writers have made to the development of the national literature and their uniquely Balinese themes. For non-Balinese readers of Indonesian literature, prior knowledge of Balinese culture is not necessary, because the theme is often discussed within a universal context such as a conflict between tradition and modernity or intergenerational disagreements.

The following analysis focuses on ways in which Balinese writers of novels and short stories have approached the matter of caste. ${ }^{6}$ This discussion focuses on selected short stories, novels and a play published by Balinese writers between 1920 and 2000. They are written by people from both triwangsa and jaba backgrounds, whose status can be clearly identified through the title in their name: for example, the titles Ida Bagus, Ida Ayu, Cokorda, Agung and I Gusti denote triwangsa status. Writers from the 1920s were commoners who joined the exclusively jaba organization Surya Kanta and felt the need to articulate the interests of lower-caste people. Their works can be seen as a voice struggling for equal status for those belonging to the lowest caste. Writers of the revolutionary, New Order and Reformation periods consisted of equal numbers of triwangsa and jaba, but most of their works, regardless of the author's own caste, express a strong anti-caste sentiment. Balinese prose writers of these periods share the view that the hierarchy and inequality imposed by caste is irrelevant to modern values. As much of the literature about caste revolves around caste conflict and status difference in the context of intercaste marriage, a brief background to intercaste marriage is provided here. 
Intercaste marriage and status

Intercaste marriage, a union between a man and a woman from different castes, has social and religious consequences, especially for the bride. There are two types of intercaste marriage. The first is a marriage between a lower-caste woman and an upper-caste man - hypergamy - in which the status of the woman is raised, but not to her husband's level. Despite her uplifted status, she is regarded as a second-class triwangsa because she has achieved her status by marriage and not by birth. Nevertheless, her new status means that she now deserves particular respect from relatives of her natal family, for example in the way she is addressed. As the Balinese language has several social registers, her maternal parents and other family members will have to speak 'up' to her and to her husband in a higher register. Because of her higher status, she does not have automatic permission to pay homage to her parents when they die, which is generally a cause of deep sadness.

The second type of intercaste marriage is one between a high-caste woman and a man of lower caste - hypogamy - which results in the woman losing her caste status and being disowned by her parents. In these marriages, the bride's family asks the groom's family to perform a ritual called patiwangi, which will release her from her caste, before the wedding ceremony to ensure that the bride and the groom have equal status. Although patiwangi is no longer compulsory since the 1951 reform of the marriage laws, many upper-caste families still prefer it, or else the groom's family perform it voluntarily to ensure that the wedding ceremony goes smoothly. Hypogamous couples who choose not to perform a patiwangi ritual may hold one later on, for instance because they have suffered a series of misfortunes such as incurable illnesses or an inability to conceive after a considerable period of marriage. In these cases, the reason for performing the ritual is a practical one, and not simply to release the woman from her caste status.

In both hypergamous and hypogamous marriages women are refused permission to pray at their family temples (Parker 2003:167), meaning that there is a loss of spiritual connection with their ancestors. As women have to bear most of the consequences 
of intercaste marriage, they suffer gender inequality as well as caste discrimination. Because of this, both triwangsa and jaba people prefer marriage within their caste group - endogamy - so that status change and all its complex consequences can be avoided. However, modern education, employment and other social connections between people of different castes make it much more difficult to prevent intercaste marriages nowadays than was the case in the past.

In pre-colonial Bali, hypergamy was always permitted, but hypogamy was prohibited. Creese's recent study on Balinese precolonial law codes discusses the harsh punishments possible in hypogamous cases, but suggests that these penalties were negotiable and that money could be paid as substitution (Creese 2008:19). During the colonial period, this long-standing prohibition of intercaste marriage was reinforced by a council of Balinese kings through a Paswara 1910 (1910 Regulation). This still carried a severe penalty, including a fine and exile from Bali. Upper-caste people, especially brahmana, supported this regulation and wanted exile to be kept as a punishment (Bagus 1996:114). Lower-caste people, by contrast, challenged it strongly. During the debate between Surya Kanta and Bali Adnjana, an editorial note in Surya Kanta in 1926 complained that the 1910 marriage law was unfair because it only applied to jaba. ${ }^{7} \mathrm{~A}$ writer using the nom-de-plume Kobar supported this point, stating that if a male commoner married an upper-caste woman, he would be fined or exiled to Jembrana (West Bali) or Lombok. ${ }^{8}$

The Dutch colonial government wanted to remove exile as a form of punishment because it was no longer seen as acceptable in a modern system of government (Bagus 1996:114), but they wanted to do it gradually so that it did not disturb Balinese adat, which had strong roots in the community (Putra Agung 2001:127). When a leader of Surya Kanta, I Nengah Metra, married a woman of the highest caste, Ida Ayu Mas Mirah, the case was not filed in court, but the couple were relocated to Lombok as if they were being exiled. They were not genuinely 'exiled', because in Lombok Nengah Metra was allowed to continue working as a teacher (Putra Agung 2001:127), and from

See 'Kaum jabakah yang tiada tahu membalas guna', Surya Kanta 2 (1926):92-3.

Surya Kanta 2 (1926):130-1. 
there he continued to promote his ideas of equality and modernity by writing for Surya Kanta. He also established social organizations such as Clubhuis Ekatjita (Solidarity Clubhouses), which was dedicated to education and among its various activites ran reading groups (Vickers 2000:97), once again promoting modernity.

The debate about marriage law led to the replacement of the 1910 Regulation by the 1927 Regulation. This new regulation, ratified by the Dutch colonial government, contained much lighter penalties. For example, offenders would not be exiled outside Bali but on the island for a maximum of ten years, and they could be fined between 25 and 100 rupiah, or imprisoned for six weeks to six months. ${ }^{9}$ Objections from lower-caste people about the discriminatory aspects for the social hierarchy in terms of triwangsa against jaba continued through the 1930s and after independence (Schulte Nordholt 2000). The long struggle to end the caste-based social hierarchy finally bore fruit in 1951, when the Balinese provincial government issued Regulation no. 11/1951 (Pitana 1997:95). This regulation completely removed the prohibition against intercaste marriage. The reasons given for this major change were that the law was no longer relevant in the post-independence era and that discrimination against particular groups should be avoided (Wiana and Santeri 1993:119). This new regulation formally legalized intercaste marriage and was also an acknowledgment that triwangsa and jaba were equal.

Although the prohibition on intercaste marriage no longer exists, meaning that the patiwangi ritual is no longer compulsory, in reality parents often perform the ritual in hypogamous marriages. There has been recent discussion of this, some of which has been published in the local newspapers, calling for the abolition of patiwangi. ${ }^{10}$ This public outcry forced the Parisada Hindu Dharma Indonesia (Parisada, highest Hindu Council) at its meeting on 26-29 October 2002, in Mataram, Lombok, to issue a decree revising what they understood to be a long-standing misunderstanding of the caste

\footnotetext{
9 'Peswara 1927 (19/20 January)', Surya Kanta 3 (1927):82-3.

10 See 'Perkawinan dan pati wangi', Bali Post 4-10-1998:5; 'Mengintip perkawinan warga Bali di Lombok (3), anaknya dibuang, itu terjadi kalau tak direstui', Bali Post 1-8-2003.
} 
system. The decree, called Pengamalan Catur Warna, ${ }^{11}$ contains 11 clauses including those confirming the withdrawal of the ban on hypogamy and the abolition of patiwangi. ${ }^{12}$ There is a reference to the removal of the prohibition against intercaste marriage in the 1951 law. This reference emphasizes that this attempt to abolish the traditional social hierarchy does not set a new precedent. The way Balinese literary works approach caste is the subject of the following discussion.

\section{Caste in the play Kesetiaan perempuan}

The play Kesetiaan perempuan deserves detailed analysis because it uses caste as its main theme and is the only dramatic work published in the 1920s, when the most popular genre was poetry. The play was serialized in three parts in Surya Kanta between March and June 1927. It takes the form of tooneel, or realist theatre, as indicated by its subtitle - 'a tooneel in three parts' (tooneel dalam 3 bahagian). In the 1920s, performances of modern theatre forms like tooneel and stamboel (Malay musical theatre) were common in Bali and attracted large Balinese audiences (Putra 2008). These performances might have inspired the writing of this play, but no information is available as to whether it was ever staged.

Kesetiaan perempuan was published during the most heated period of the debate between Surya Kanta and Bali Adnjana over caste issues.

11 'The Implementation of Four Warna'. See ‘Bhisama catur warna dan kemerdekaan beragama', Bali Post 30-10-2002. The decree intentionally uses the term 'warna' (which literally means 'colour') to change incorrect uses of the caste system. Unlike the caste system, 'the warna system' defines someone's status by their duty or profession. Under this system, status is achieved, not ascribed, and can change accordingly. For example, the title brahmana is only for those who perform duties as priests and so children of priests do not necessarily hold the title brahmana. Members of one family could hold different warna identities according to their profession.

12 See the Decrees of the Central Council of Parisada Priests, X/2002. The withdrawal of the ban on hypogamy is stated in article 9 (Perkawinan yang disebut kawin nyerod harus dihapuskan), while the total abolition of patiwangi is stated in article 10 (Upacara adat Patiwangi harus dihapuskan sejalan dengan hapusnya tradisi Asumundung dan Karang hulu oleh Dewan Pemerintah Bali Tahun 1951). 
A footnote to the play suggests that it had been written before the replacement of the 1910 Regulation by the 1927 Regulation, which means that it was written when the more severe penalties were still in place. The theme of the play and the timing of its publication indicate that it was used by Surya Kanta to protest about the unfairness of the caste system and intercaste marriage penalties.

The play presents the reader with a courageous upper-caste woman who challenges her father after his refusal to approve her marriage to her lower-caste boyfriend because of the status difference. The main characters in the play, whose names are all based on former Balinese kingdoms, are Gusti Made Sekowati, a triwangsa woman, her father Gusti Ngurah Tabanan, a punggawa (district head) and her boyfriend Ketut Badung, a jaba man who works as a police officer and is soon to receive a promotion to district head. The play gives the arguments that Ngurah Tabanan uses to try to stop his daughter from marrying Ketut Badung, saying that it will make his daughter lose her nobility and bring shame on him and his extended family.

In order to prevent the marriage, Ngurah Tabanan attempts to break up the relationship. He locks Sekowati in her room, so that she and her boyfriend cannot contact each other. Sekowati is upset and bravely argues with her father, leading to a conflict in which caste and self-esteem, rank and character, and the consequences of intercaste marriage from a triwangsa viewpoint are debated. The following conversation takes place in Sekowati's room.

GUSTI NGURAH TABANAN: (angrily) So, you are in love with Ketut Badung. Oh, my child! This love of yours will destroy you, this love for someone who is not a noble, but is a commoner!

GUSTI MADE SEKOWATI: Father! If I am standing up to you today, you yourself, father, have caused me to do so. Ketut Badung is not a commoner, not a lowly person. His character (budi pekerti) is no lower than that of any noble. And what do you consider, father, to be the measure of high or low rank other than character - wealth? Oh, father! I have made a promise to Ketut Badung, if I broke that promise, would I still be a noble person?

GUSTI NGURAH TABANAN: (increasingly angry) Be quiet, rebellious child! Do you have so little affection for me that you will expose yourself to shameful behaviour that will destroy your reputation and your caste position? And besides, it will not be you alone who will suffer, but I, too, 
and all your relatives will be degraded and shamed, as a result of your

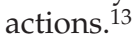

It is interesting that the protest is presented through the female triwangsa protagonist, while the male character, her jaba boyfriend, has comparatively little to say. Sekowati is depicted as having a modern view of caste. She rejects the conventional idea of defining rank by caste or wealth but proposes instead that it should be defined by budi pekerti (moral character). The term budi was a key concept promulgated by Surya Kanta during the caste debate with Bali Adnjana and was employed in arguing the importance of achieved rather than ascribed status. The ways the term is used in Kesetiaan perempuan indicate its writer's intention to echo Surya Kanta's anticaste spirit. In the argument with her father, Sekowati insists that although Ketut Badung was born a commoner, he is 'not a lowly person'. He has achieved a relatively high position in the Dutch colonial bureaucracy.

By contrast, Sekowati's father, I Gusti Ngurah Tabanan, is represented as a person with a conventional view of caste. Although Ketut Badung has gained considerable status, Ngurah Tabanan continues to consider him a commoner, someone whom Sekowati should not marry because by doing so she will lose caste rank and bring shame to her extended family. These opposing attitudes to

13 GUSTI NGURAH TABANAN: (marah) Jadi masihlah juga kau menaruh cinta kepada Ketut Badung. O, anakku! Tiadakah sayang kamu akan merusak dirimu, bercinta kepada seorang yang tak berbangsa, seorang sudra.

GUSTI MADE SEKOWATI: Bapak! Jikalau hamba sekarang ada berani kepada ayahnda, ayah sendirilah yang menyebabkannya. Ketut Badung bukannya seorang sudra, bukannya seorang yang hina. Tentang budi pekerti tiadalah kalah ia dari kaum triwangsa. Dan apakah dalam pendapatan ayahnda, harta itukah yang menjadi ukuran tinggi rendahnya derajat budi manusia? Oh ayahnda! Hamba telah berjanji dengan pasti kepada kanda Ketut Badung. Apakah jika anaknda tiada menepati janji, kesatriakah namanya?

GUSTI NGURAH TABANAN: (bertambah marah) Diam, engkau anak durhaka! Engkau tiada sayang akan terjun dalam kubangan yang mengoyak-oyakkan nama dan kebangsaanmu. Dan lagi tiada hanya engkau saja yang akan menderita celaka ini, akan tetapi aku dan sekalian sanak saudaramu dihina-hinakan dan dipermalumalukan karena perbuatanmu. Surya Kanta 3 (1927). The translation is taken from Bagus (1996:107-8) with minor revisions. 
caste are the cause of the conflict between father and daughter, and remain unresolved.

At the climax of the story, Ketut Badung smuggles Sekowati out of her room so that they can elope. Ngerorod (elopement) is a romantic form of marriage to which couples resort when approval from the woman's parents is not forthcoming. It was one of the legal forms of marriage in pre-colonial times and is still practised in presentday Bali. ${ }^{14}$ It is a way of resolving intercaste marriage situations, and also marriages between people of the same rank, where permission has been denied by one or both sets of parents. Predictably, Ngurah Tabanan interprets the elopement of Ketut Badung and Sekowati as an act of personal humiliation. As a district head, the angry Ngurah Tabanan discusses this violation with the members of his Raad Kertha (Court of Justice) and supports their decision to punish the couple.

When the couple come to Ngurah Tabanan to seek his forgiveness, their apology is rejected and instead they are punished. Ngurah Tabanan terminates Ketut Badung's employment as a police officer and consequently Ketut Badung loses any chance of being promoted to district head. In addition, the couple are exiled: 'Both of you, leave this country!'15

14 The other two kinds of marriage are melegandang (marriage by forced abduction) and memadik (arranged marriage). Melegandang is a form of marriage which results from a woman being captured and abducted by the potential groom. Although the bride may not love the groom, she is expected to gradually accept the new reality, as the alternative of returning home would only cause her and her family shame. Memadik involves set procedures, from the delivering of the marriage proposal to the final wedding ceremony. The bride's parents usually prefer this 'arranged' type of marriage because it is a way for them to show that they are a respected family. However, since this type of marriage is frequently complicated, many people choose to elope and then make sure that the proper ceremonies are carried out afterwards. This often occurs because a high-caste family is ashamed to accept a marriage proposal from a low-caste family, leaving elopement as the best path. Creese (2004a:89) includes elopement as a form of 'capture marriage'. Abduction is clearly another form of 'capture marriage' and both types are common in classical Balinese literature. For a detailed description of types of marriage and the procedures used in Bali, see Pitana 1997:96-101.

15 'Enyahlah engkau kedua dari negeri ini!', Surya Kanta 3 (1927):76. 
As the couple depart, Ngurah Tabanan begins to cry and to regret his decision, because in his heart he still acknowledges Sekowati as his daughter. ${ }^{16}$ The story concludes with the three main characters all suffering. This tragic ending illustrates how the intercaste marriage laws had an impact on both jaba and triwangsa, and the play indirectly reveals how the elimination of the intercaste marriage prohibition and caste differences also affect the interests of triwangsa.

The naming of the characters in Kesetiaan perempuan is very interesting. The names Badung, Sekowati (Sukawati), Tabanan, and Gianyar (Tabanan's brother) are those of former kingdoms of Bali. The wars between these kingdoms meant that Bali was far from united in the pre-colonial era. In 1808 the kingdoms of Tabanan and Badung engaged in a war, and from the 1820s onward war broke out again between the kingdoms of Gianyar and Badung and other kingdoms (C. Geertz 1980:44). These wars caused deep suffering to the populace, particularly to jaba people. Thus, in the play, the conflict between Tabanan and Gianyar on one side and Badung and Sekowati on the other can be taken as an allegory of inter-kingdom rivalries. Alternatively, the allegory can be seen as a negative portrayal of upper-caste Balinese rulers.

Although the text was published anonymously, the content of the play echoes the personal experience of I Nengah Metra (see above), a prominent jaba leader of Surya Kanta who married a brahmana woman, Ida Ayu Mas Mirah, in 1926. It is possible that Nengah Metra wrote or contributed to the writing of Kesetiaan perempuan before his relocation to Lombok (Bagus 1996:103). But what is more important than the name of the writer is the play's message, which clearly articulates strong anti-caste sentiment. Like the poetry that Surya Kanta also published, this play was used as a vehicle for attacking the discriminatory character of the caste system and stating its preference for modern identity.

16 'Akan tetapi, meskipun dibagaimanakan juga, ia masih anakku! O, Sekowati, jantung hatiku!', (However, whatever happened, she is still my daughter, O, Sekowati, my heart). 
Intergenerational caste conflict

The intergenerational conflict about caste in Kesetiaan perempuan became a narrative model frequently used by Balinese writers between 1960 and 2000. A selection of stories from this period shows that almost two-thirds of them use the theme of intergenerational conflict in the context of intercaste marriage (see Table 7). Through the issue of the conflict between triwangsa and jaba, caste and equality as well as tradition and modernity are discussed. The stories depict contrasting views and attitudes concerning traditional status between parents and their children. The parents are presented as representatives of an old-fashioned generation who have strong convictions about maintaining the traditional hierarchical social structure, while the children are shown as a young generation with modernist views who find traditionally defined status discriminatory and think it should be abolished. Opposition to the existing caste system is usually voiced by narrators through these younger characters, regardless of their caste. Elopement is a common way of challenging parental disapproval of intercaste marriage chosen by young people of different castes.

Table 7. A list of short stories and novels dealing with caste

\begin{tabular}{llcl}
\hline No. Title & Year & $\begin{array}{c}\text { Author / } \\
\text { caste }\end{array}$ & Theme(s) \\
\hline
\end{tabular}

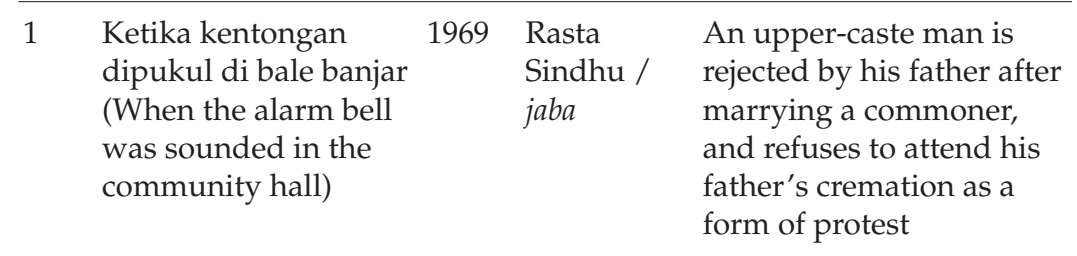

2 Bila malam bertambah 1971 Putu malam (As the night Wijaya /

A hypocritical upper-caste grows darker)* triwangsa woman finally confesses that her son's biological father is a commoner

\section{Kawin lari} (Elopement)

1972 Faisal

Baraas /

Balinese-

Muslim
An upper-caste father tells a commoner to elope with his daughter while pretending to disapprove 


\begin{tabular}{|c|c|c|c|c|}
\hline No. & Title & Year & $\begin{array}{l}\text { Author / } \\
\text { caste }\end{array}$ & Theme(s) \\
\hline 4 & $\begin{array}{l}\text { Mega hitam pulau } \\
\text { khayangan } \\
\text { (Black clouds over the } \\
\text { isle of gods) }\end{array}$ & 1978 & $\begin{array}{l}\text { Putu Oka } \\
\text { Sukanta / } \\
\text { jaba }\end{array}$ & $\begin{array}{l}\text { A brahmana woman } \\
\text { and a commoner elope } \\
\text { to Jakarta to overcome } \\
\text { local disapproval of their } \\
\text { marriage }\end{array}$ \\
\hline 5 & $\begin{array}{l}\text { Sembilu dalam taman } \\
\text { (Grief in the park)* }\end{array}$ & 1986 & $\begin{array}{l}\text { Ngurah } \\
\text { Parsua / } \\
\text { triwangsa }\end{array}$ & $\begin{array}{l}\text { Conflict between a } \\
\text { triwangsa father and } \\
\text { son, caused by the son's } \\
\text { intention to adopt his } \\
\text { baby from his former } \\
\text { commoner girlfriend }\end{array}$ \\
\hline 6 & $\begin{array}{l}\text { Mendung di kuri gede } \\
\text { (Clouds over the kuri } \\
\text { gede) }\end{array}$ & 1991 & $\begin{array}{l}\text { Oka } \\
\text { Rusmini / } \\
\text { triwangsa }\end{array}$ & $\begin{array}{l}\text { A brahmana woman who } \\
\text { married down encourages } \\
\text { her daughter to marry up } \\
\text { to end her feelings of guilt } \\
\text { to her ancestors }\end{array}$ \\
\hline
\end{tabular}

$7 \quad$ Tembok puri

1993 Aryantha A commoner woman who (The palace wall)

Soethama / has married up faces a jaba dilemma when she wants to take part in a ritual in her parents' house

8 Hunus (Unsheathed)*

1994

Sunaryono Basuki/ A triwangsa woman is Javanese after marrying a British Muslim man

$9 \quad$ Bohong (Lies) 1994 Aryantha The parents of a Soethama / commoner man refuse jaba to provide a patiwangi offering in an intercaste marriage

10 Putu menolong Tuhan 1994 (Putu helps god)

Oka Rusmini / brings misfortune to the triwangsa couple's family 


\begin{tabular}{|c|c|c|c|c|}
\hline No. & Title & Year & $\begin{array}{l}\text { Author / } \\
\text { caste }\end{array}$ & Theme(s) \\
\hline 11 & $\begin{array}{l}\text { Sekarang dia } \\
\text { bangsawan (He is an } \\
\text { aristocrat now) }\end{array}$ & 1996 & $\begin{array}{l}\text { Aryantha } \\
\text { Soethama / } \\
\text { jaba }\end{array}$ & $\begin{array}{l}\text { A man purchases noble } \\
\text { status after success in his } \\
\text { tourism business }\end{array}$ \\
\hline 12 & $\begin{array}{l}\text { Gurat-gurat } \\
\text { (Scratches)* }^{*}\end{array}$ & 1996 & $\begin{array}{l}\text { Oka } \\
\text { Rusmini / } \\
\text { triwangsa }\end{array}$ & $\begin{array}{l}\text { A brahmana woman } \\
\text { who gives birth outside } \\
\text { marriage allows her baby } \\
\text { girl to be brought up } \\
\text { by a commoner family. } \\
\text { The woman adopts her } \\
\text { daughter as her servant } \\
\text { but she retains commoner } \\
\text { status. }\end{array}$ \\
\hline 13 & Kenanga* & $\begin{array}{l}2003 \\
{[1996]}\end{array}$ & $\begin{array}{l}\text { Oka } \\
\text { Rusmini / } \\
\text { triwangsa }\end{array}$ & $\begin{array}{l}\text { This is a revised version } \\
\text { of Gurat-gurat (see } 12 \\
\text { above) }\end{array}$ \\
\hline 14 & Sagra & $\begin{array}{l}2004 \\
{[1998]}\end{array}$ & $\begin{array}{l}\text { Oka } \\
\text { Rusmini / } \\
\text { triwangsa }\end{array}$ & $\begin{array}{l}\text { A commoner woman } \\
\text { finally discovers that her } \\
\text { biological father was a } \\
\text { brahmana man }\end{array}$ \\
\hline 15 & $\begin{array}{l}\text { Tarian bumi (The } \\
\text { dance of the earth)* }\end{array}$ & 2000 & $\begin{array}{l}\text { Oka } \\
\text { Rusmini / } \\
\text { triwangsa }\end{array}$ & $\begin{array}{l}\text { A brahmana woman } \\
\text { engages in hypogamy and } \\
\text { commits to leaving the } \\
\text { caste she never wanted to } \\
\text { be born into }\end{array}$ \\
\hline
\end{tabular}

* novels

As in Kesetiaan perempuan, in the works discussed below, disputes over caste take place between parents and children from triwangsa families. These disputes provide plentiful narrative material about how people from the same caste background can still argue about status, self-esteem, love and humanity. The heroine of Putu Oka Sukanta's short story 'Mega hitam pulau khayangan' (Black clouds over the isle of gods, 1978) is a brahmana woman, Ida Ayu Sumartini, who opposes her parents when they oppose her plan to marry her 
commoner boyfriend because of the caste difference. Dayu Sumartini is a modern woman whose parents send her to continue her studies in Jakarta, where she meets her boyfriend, Nyoman Astawa, a lowercaste man. Her parents try to terminate her relationship with her boyfriend through various means, including the use of a shaman's mystical power, but all their efforts fail.

Dayu Sumartini argues resolutely with her parents, asking why her elder brother is allowed to marry a person of lower caste while she is constantly denied permission to do the same. Her objections include ideas of humanity and gender inequality as well as caste. After emphasizing that human beings are equal before God, she points out that the caste system is just like an uncomfortable traditional costume that should be discarded. Her mother is upset and sarcastically asks if her radical attitude towards custom is caused by education. She finally flies off to Jakarta with her boyfriend, leaving her parents in Bali devastated. From the plane, the couple look down and see 'black clouds hanging over the island of Bali'. The conclusion of the story is well connected to its title, which is a metaphor for the taint imposed on Balinese culture by the caste system. ${ }^{17}$

The Indonesian poet and critic Toeti Heraty Noerhadi (1991), in her introduction to Sukanta's short-story collection Keringat mutiara which includes 'Mega hitam pulau khayangan', emphasizes the heroine's bravery in leaving the family and culture that have constrained her freedom through the caste system. Simultaneously, she raises questions about the future of the young heroine and her husband, uprooted from the security of their culture in Bali, whose life in Jakarta, a completely new place and context, is held together only by love (Noerhadi 1991:xi). Toety Heraty Noerhadi's comments are valid, but the central idea of the story is not how the couple will face the future but rather how they have opposed and overcome the traditional values that have interfered with their current lives.

A conflict over caste between a mother and her daughter is also a focus of Sunaryono Basuki's novel Hunus (Unsheathed, 1994). But alongside this theme, the novel gives almost equal weight to

17 The expression 'cloud' is also used with a similar meaning in Oka Rusmini's story Mendung di kuri gede (Clouds over the kuri gede, 1991) discussed below. 
exploring the magical power of the Indonesian keris (dagger). Both ideas are suited to its general theme of cross-cultural conflict between East and West. As in the previous story, in this novel the female character is an upper caste ksatria woman, Agung Ari Maharani, whose parents threaten to cast her out if she marries a lower-caste man. She is presented as a modern Balinese woman who goes to university in Jakarta and completely rejects traditional values such as the caste based social hierarchy. Her determination to elope with her boyfriend, a British man named Anthony Wright, upsets her family who subsequently disown her. Ultimately, her punishment is of no significance because Maharani and Tony move to London, far away from Balinese caste complications. In both stories, the central characters are young women who have modern education and who are used by the authors to voice objections to traditional values that are irrelevant to the modern era. The women evade their difficulties by leaving Bali. In addition, these stories illustrate that there are specific problems that women have to face in intercaste marriage and that they have ample reason to protest.

While these two stories describe the way parents reject triwangsa women who oppose the caste system by entering hypogamous relationships, Rasta Sindhu's story 'Ketika kentongan dipukul di bale banjar' (1969), by contrast, depicts a father disowning his son after he marries a commoner. Expulsion of a man as a result of intercaste marriage is uncommon, but here the writer uses this theme to show the difference in attitudes toward caste between a father and his son, respectively representing the old, traditionalist generation and the young, modernist generation. The conflict begins when the father urges his son, Anak Agung Gde Lila, to marry a bangsawan (noble woman), and warns that if he marries Sulastri, a woman of lower rank, no wedding ceremony will be held and he will be expelled from the family. Sulastri's family find out about the tensions between Gde Lila and his father and understandably feel offended. At this point, the conflict expands from one between Gde Lila and his father to one between the two families. Sulastri's father considers Gde Lila's father kolot (backward) and withdraws his permission for Sulastri to marry Gde Lila: 'Just abandon your plans to marry Gung Gde Lila. You've heard the decision of his family, haven't you? They all 
disparage our status. But we do have status, although it is not that of nobility. We have status, that is the status of being human. ${ }^{\prime 18}$ As Gde Lila and Sulastri are deeply in love with each other, they elope. Gde Lila picks up Sulastri from her school, rather than from her home, and they stay temporarily at the house of one of Gde Lila's friends. Although the couple realise their desire to marry, they are denied complete happiness because they both suffer expulsion from their families. Because he does not receive any allowance from his rich father, Gde Lila suffers economically. He has to borrow money to live but nevertheless refuses to seek financial help from his family members who continue to humiliate him.

Hostility between Gde Lila and his family over the issue of rank continues. At the climax of the story, he refuses to attend his father's cremation. This is a quite extreme decision in terms of Balinese religious and cultural values. It is a social obligation in Bali for children to carry out a cremation for their parents. This is a way of paying their last respects to the deceased parent, but it is also socially incorrect for them to stay away from this ritual when other members of the community have come and given their support to carry out the ceremony. Speaking to the messenger who brings news of his father's death, Gde Lila reiterates his refusal to attend by declaring: 'he has no longer been my father since he disowned $\mathrm{me}^{\prime 19}$ and replies to his wife, who encourages him to return to his puri (palace) to attend the cremation: 'I am no longer part of the palace family. ${ }^{20} \mathrm{He}$ is actually very distressed at being unable to attend the cremation, as it will be his final chance to pay respect to his father. The unreconciled tension of the ending continues the strong sense of conflict in this story, which won the Horison award for best short story in 1968.

In 1993, Ketika kentongan dipukul di bale banjar was made into a sinetron by the regional arm of the state channel, TVRI Denpasar. When this sinetron was replayed on 11 May 2002, it still received a

18 Kau urungkan saja niatmu untuk kawin dengan Gung Gde Lila. Kau sudah dengar keputusan keluarganya, bukan? Semuanya merendahkan derajat kita. Kita pun punya derajat, walaupun bukan derajat bangsawan. Kita punya derajat, yaitu derajat kemanusiaan. (Rasta Sindhu 1969.)

19 Beliau bukan ayah saya lagi sejak beliau membuang saya.

20 Aku bukan keluarga Puri lagi. 
positive response (I. Wirata 2002) There was even a suggestion that the sinetron should be re-broadcast or a play performed live at the Bali Arts Festival, because this would be an excellent way to remember Rasta Sindhu as one of Bali's most talented modern writers. One reason that the story has been able to maintain public attention so strongly, many years after its initial publication, is that caste conflict remains a major point of contention in Balinese public discourse, even in the twenty-first century.

Each of the stories discussed above features intergenerational caste disputes within families from upper-caste backgrounds. Older people vehemently maintain the caste system out of self-interest and protect caste privileges by anchoring them to adat, while their children oppose it because it deprives them of the essential freedom to choose their spouses and the future course of their lives. One exception to this uniform approach is Faisal Baraas's Kawin lari. The main character is a man of triwangsa rank, Gung Semara, who describes himself as living in two contrasting worlds: traditional and modern. Being an educated man who has travelled around Europe, he is aware of being part of the modern world - but being a member of an upper-caste family and a village leader, he must also honour traditional practices even when he does not necessarily agree with them. When a young professional man, a doctor, who is nonetheless only of commoner status, comes to him to ask permission to marry his daughter, Gung Semara advises the young man to elope, even though he knows his extended family members are going to deliver a marriage proposal for his daughter later that day. To avoid upsetting his extended family and to save face in front of them, Gung Semara sets out a scenario for his prospective son-in-law to follow: 'Come back later. Make an announcement about what you've done, when our entire family is gathered, in the way that people who've eloped usually do. It might be better if you come with your village headman. So that you'll be safe. I might need to hit you afterwards!'21 The young man agrees. The story ends with Gung

21 Datanglah kembali nanti. Memberitahu peristiwa itu, ketika seluruh keluarga kami berkumpul, sebagaimana dilakukan oleh orang yang kawin lari. Sebaiknya Anda datang dengan didampingi oleh Kepala Banjar. Agar engkau selamat. Barangkali aku perlu memukulmu nanti! 
Semara well-satisfied, releasing a long slow breath, a symbol of his freedom from this caste related burden. Gung Semara's willingness to compromise represents the attitude of many modern triwangsa who are psychologically conflicted by the requirements of caste based customs and traditions but choose not to oppose them openly. As increasing numbers of educated triwangsa find themselves in situations like that of Gung Semara, the experience of confronting his dilemma has become more common. All of the stories above, whether dramatically or calmly, oppose any differentiation between jaba and triwangsa people because this distinguishes human beings according to their birth and is incompatible with the spirit of modernity. The characters who oppose the caste system are those with a high level of modern education, who are living in cities and recognize how the traditional hierarchy imposes more restrictions on modern life than alternative ways do.

\section{The tragedy of intercaste marriage}

Other Balinese writers contest the caste system through stories about the unhappy lives experienced by women in both forms of intercaste marriage. One Balinese writer who writes extensively about the tragedy inherent in intercaste marriage is Oka Rusmini. She was born in Jakarta into a brahmana family in 1967, but lives in Bali. She is married to a Javanese-Muslim poet and essayist, Arief B. Prasetyo, but this union 'so upset her family on account of his ethnicity and religion that they disowned her' (Allen 2001:32).

Oka Rusmini has published three poetry collections, two novels, and a collection of short stories, ${ }^{22}$ most of which focus on caste. Two of these stories, Putu menolong Tuhan and Sagra, won awards in a national literary competition held by the women's magazine, Femina, in 1994 and 1998 respectively. Horison selected another story, Pemahat abad (The carver of the century), which deals with the theme of

22 Her publications include the poetry collections Monolog pohon (Tree Monologue, 1997), Patiwangi (2003) and Warna kita (Our colour, 2007), the novels Tarian bumi (2000) and Kenanga (2003a), and a short story collection entitled Sagra (2001). 
hypergamy, as the best short story for the period 1990-2000. Her novel Tarian bumi (2000) has also been extremely popular, as evidenced by its seven printings totalling 33,000 copies between 2000 and 2007,23 a significant success by Indonesian standards. A German translation, Erdentanz, was published in 2007, further widening its readership. All of these achievements havebroughtOka Rusmininational recognition, as evidenced by her inclusion in Angkatan 2000 (Generation 2000), an anthology of significant contemporary Indonesian writers (Rampan 2000). She is one of a growing number of women writers who write from a female perspective and who have risen to prominence since the fall of the New Order. Her works reflect the lack of harmony in the relationship between her and the brahmana family who disowned her, while they also provide prominent roles for female characters, especially so that they can voice their opposition to the caste system.

Tarian bumi is a novel that focuses on the tragic consequences of intercaste marriage for four generations of a family. This novel has an interesting cyclic plot that describes the movements of women's lives from the lowest to the highest caste (jaba to brahmana) and then back to jaba. Initially a commoner woman marries into a higher caste brahmana family. Later her brahmana daughter marries a person of jaba origins. The four generations of women are Ida Ayu Telaga or Dayu Telaga, ${ }^{24}$ aged in her thirties, her grandmother, her mother (Luh Sekar) and her daughter. Each of these women holds different attitudes toward caste status and all that it is assumed to imply. Luh Sekar represents marrying up, while her brahmana daughter Dayu Telaga represents marrying down. Because of status differences, neither is welcomed by her husband's family members and so both suffer personal discrimination.

Luh Sekar is born into a poor family, which suffers social exclusion

\footnotetext{
23 Oka Rusmini, personal communication, 23-7-2007. The first printing of the novel was by the publisher Indonesia Tera which then reprinted the novel another five times, with each print run of 5000 copies (between 2000 and 2006). In July 2007 Gramedia, one of the biggest publishers in Indonesia, printed the novel for the seventh time in a run of 3000 copies. Before appearing as a book, the novel was serialized in the daily newspaper Republika from 4-3-1997 to 8-4-1997.

24 Ida Ayu is often shortened to Dayu, thus Ida Ayu Telaga is called Dayu Telaga, Ida Ayu Bulan becomes Dayu Bulan and so on. The term Dayu is used here.
} 
and political suppression as a result of her father being killed in 1965 for his alleged involvement in the communist party. Luh Sekar is urged by her mother to improve their lives and to enhance the status of the family by marrying a rich man of the highest caste. Luh Sekar, who is described as a beautiful and talented dancer, accepts her mother's advice and becomes obsessed with the idea of marrying a man of the highest caste, as she explains to a friend: 'I'm tired of being poor, Kenten. You must know that. Please, help to find me an Ida Bagus [a man of the highest caste]. Whatever price I have to pay, I will do it!' ${ }^{25}$ Luh Sekar's ambition to marry a brahmana is clearly motivated by economic need as well as the desire to release her family from social exclusion and political oppression. This story gives an image of the brahmana as economically better off and politically powerful, although in contemporary Bali they are not necessarily dominant in either area. By depicting them as having extraordinary economic and political power, the author is able to create a gap between the highest and the lowest caste so that the process of upward status mobility seems more desirable. Being a talented dancer, Luh Sekar is able to attract a brahmana man who eventually marries her. Her mother is delighted, congratulates her on being born as a new woman, and gives her a special present, a tusuk konde (hair pin) (Rusmini 2000:44).

Tusuk konde and other items of jewellery are treasures that almost every Balinese mother is proud to possess and wishes to pass on to her daughters as a symbolic expression of fondness. They can either be inherited from their own mother, or be acquired during life. This holds deep symbolism for all Balinese women, who hope to receive tusuk konde, whether inherited or not, to pass on to their own children. Towards the end of the story, readers see that the same tusuk konde is passed on by Luh Sekar to her daughter. Far from being trivial information, in this story the tusuk konde is highly significant and is cleverly used by the author to describe the special relationship between mother and daughter, and also to strengthen the cyclic plot of the novel by using it as a repeated narrative element. In some of Oka Rusmini's other works tusuk konde recurs as a motif.

25 Aku capek miskin, Kenten. Kau harus tahu itu. Tolonglah, carikan aku seorang Ida Bagus. Apa pun syarat yang harus kubayar, aku siap! (Rusmini 2000:17.) 
Once she is the wife of a brahmana, Luh Sekar's name is changed to Jero Kenanga and her world changes irrevocably. This new identity severs all her spiritual links with her family members and ancestors. She can no longer pray in her family temples and consume the food and fruit left over from the family offerings or share meals with her family. Change in status pushes her to the margins of social and religious interaction. She is considered as 'Other' from both sides. In her husband's family, she is considered a lower-caste person, while in her own family she must be considered a bangsawan tulen (true noble woman) (Rusmini 2000:45). When her mother dies, Jero Kenanga is not allowed to touch her mother's corpse or pray over it because her status as the wife of a brahmana is higher than that of her dead mother (Rusmini 2000:47). It is a cause of great sadness not to be allowed to pay last respects to one's parents, as discussed in the case of Gde Lila, although the context here is different.

Her new status and identity do not bring Jero Kenanga any happiness. On the contrary, she feels humiliated and oppressed and her husband does not love her at all. He continues to sleep with prostitutes and even sexually propositions her younger twin sisters. Eventually, her husband dies a fitting death in a brothel (Rusmini 2000:14), a disgraceful end for a noble person. Although Jero Kenanga has been the wife of a brahmana, has given birth to a brahmana daughter, and has lived in a brahmana house, known as a geria, for 20 years, her husband's family members have never considered her a true member of their caste. Of course she never can be, because she was not born a brahmana. Despite this discrimination, Jero Kenanga maintains a pretence of happiness and acts as an even stronger defender of the caste system than a true brahmana. She tries hard to raise her only daughter, Dayu Telaga, as an ideal brahmana and is conscious that Dayu Telaga has two of the attributes which she herself once possessed, thought to be most important for this status she is beautiful and also a talented dancer.

Dayu Telaga, however, has different aspirations. In fact, she wants to discard her brahmana status and has many reasons for doing so. She resents all the suffering that her mother has undergone, through living in a geria, and is angry at the unfounded gossip in the geria that her mother, following the death of her husband, had engaged 
in a sexual relationship with her father-in-law (Rusmini 2000:122-3). Dayu Telaga rejects her brahmana status because she has seen much immorality among that caste, including adultery. In addition, she has learnt that life as a brahmana in the geria is made oppressive by the heavy responsibilities of adat, such as making daily offerings and being involved in other regular religious and cultural ceremonies. All these factors help destroy her respect for caste status and make her confident about her decision to marry a commoner who she loves, a painter who is also her dancing partner, Wayan Sasmitha.

Dayu Telaga's hypogamous marriage distresses both her mother and her mother-in-law. This highlights the fact that disapproval of intercaste marriage cuts across all castes. Her mother disapproves of Dayu Telaga's marriage because she wants her to marry a person with the same status. Her mother-in-law Luh Gumbreg's disagreement is based on two factors: she believes that the marriage will destroy the long and good hierarchical relationship between the two families, and there is also a superstition that a hypogamous marriage is panes (hot or dangerous) and will bring misfortune. This belief tragically becomes reality when Wayan Sasmitha dies suddenly from a heart attack in his painting studio (Rusmini 2000:121). In her state of unhappiness Luh Gumbreg insists that the panes nature of intercaste marriage is like this:

'I said many times that marriage with a brahmana woman would certainly bring misfortune. Now, my son is dead! Wayan would never understand this. This is not a fairy tale. This is the truth. But now it has happened there is nothing more I can say!' Luh Gumbreg beat her breast. Her eyes were fixed unhappily on Telaga. ${ }^{26}$

The death of her husband leaves Dayu Telaga a widow with a daughter, Luh Sari, born on 30 September, which symbolically coincides with the date of the alleged communist coup in 1965. While Luh Sari's date of birth has no direct relationship to the tragic 1965 event,

26 'Berkali-kali tiang berkata, menikah dengan perempuan Ida Ayu pasti mendatangkan kesialan. Sekarang anakku mati! Wayan tidak pernah mau mengerti. Ini bukan cerita dongeng. Ini kebenaran. Kalau sudah begini jadinya aku harus bicara apa lagi!' Luh Gumbreg memukul dadanya. Menatap Telaga tidak senang. (2000:120.) 
it can be interpreted as a metaphor for the lives of Dayu Telaga and Luh Sari being thrown into chaos, as Indonesia was. Parallelling her mother's experience, becoming a widow makes Dayu Telaga's life difficult, especially since her mother-in-law does not welcome her. As an 'outsider', she is blamed for all the family misfortunes. Dayu Telaga is then asked by her mother-in-law to do two things to prevent any further misfortune from blighting all their lives - to take spiritual leave from her brahmana ancestors and to perform patiwangi (Rusmini 2000:129). This story is set in the period from the 1960s onward, when the patiwangi ritual was no longer obligatory. Yet while it is not uncommon to still see patiwangi conducted in contemporary Bali, the way the author describes it helps to explain how the caste system is deeply rooted in adat or religious practices and demonstrates how these practices could not easily be abolished by formal government regulation.

After ten years of marriage and a series of misfortunes that has engulfed her family including the sudden death of her husband, Dayu Telaga returns for the first time to her brahmana place of birth. When she and her daughter Luh Sari arrive, her mother Jero Kenanga refuses to see them. She locks herself in her room and merely gives Dayu Telaga a tusuk konde, which she had received from her own mother when she married, by throwing it underneath the door. Jero Kenanga's action in passing the tusuk konde to Dayu Telaga is a symbolic acknowledgement of the daughter she has expelled for her determination to marry down. This passing of tusuk konde contrasts sharply with the original transfer, which happened on a happy occasion because Luh Sekar's mother was pleased to see her daughter marrying up. By contrast, the second one occurs in a depressing situation because Jero Kenanga is devastated to see Dayu Telaga marrying down. If Jero Kenanga had had other daughters, she might not have chosen to pass the tusuk konde to Dayu Telaga but to the daughter she loved most.

In the ceremony that marks the conclusion of the story, Dayu Telaga prays for the last time in the brahmana compound temple where the patiwangi ritual to release her from her caste is also held. Dayu Telaga allows her grandmother, the senior woman in the compound, to place a foot on her head to symbolize her transformation from brahmana 
to commoner (Rusmini 2000:139). The act of having someone step on one's head is regarded as extremely insulting, but in this case Dayu Telaga accepts dishonour as a way of abandoning her caste and all its complexities and burdens. This novel expresses strong opposition to the caste system but at the same time it also confirms how closely this system is connected to adat practices. Those who want to abandon their caste status must follow the adat procedures that in fact perpetuate its existence, exposing the repetitive nature of these changes.

Oka Rusmini explores similar themes in some of her other works such as Mendung di kuri gede and Putu menolong Tuhan. The female characters in both of these stories are involved in intercaste marriage, and in the name of adat they too become the subjects of status discrimination from the members of their husband's families. The short story Mendung di kuri gede tells of a commoner woman, named Kendelan, who is made an object of humiliation by her sisters-inlaw after marrying a brahmana. Although Kendelan was born of a mother with brahmana blood - her mother was a brahmana who had married someone of lower caste - and has the ability to perform all the tasks and duties related to adat that most brahmana women carry out, she can never truly be part of her new brahmana family. Like Jero Kenanga in Tarian bumi, Kendelan is accepted as a member of this brahmana family but not regarded as a real brahmana - that is, she is just a second-class brahmana. She is always the subject of status discrimination.

Putu menolong Tuhan shows a family in disarray over caste and the dangers of intercaste marriage. In this story, Dayu Ratih, who has married down, receives a bleak welcome from the women in her new family. She is accused of being a witch, of practising black magic and using spells (guna-guna), which together are considered to be the causes of the ongoing bad luck in their family. Dayu Ratih's daughter, Putu, understands the lack of harmony in the relationship between her mother and her grandmother and begins to hate her grandmother. Putu considers her grandmother an evil person hated by God and so, wishing to assist God, she takes justice into her own hands and pushes her grandmother into a well, where she is later found dead. This fatal incident involving an innocent little girl emphasizes the 
strong superstition: that intercaste marriage, especially with a brahmana woman, is always panes.

The distress caused to women's lives as a result of intercaste marriage also appears as the subject matter of some of Aryantha Soethama's short stories. One of them is Tembok puri. ${ }^{27}$ As in Oka Rusmini's novels and stories, the manipulation of adat in the name of caste, and ambivalence towards modernity becomes the source of problems in this story. Tembok puri describes a marriage between a triwangsa man with modern ideas, Ngurah Parwatha and a commoner, Kadek Sumerti. From the beginning, Ngurah Parwatha has explained to his prospective wife that nowadays living in a puri is not too different from life outside and that his family members are all modern people who like to watch satellite television, have laser discs, a refrigerator and speak in Indonesian, the national language.

There is no problem with the marriage itself, but one arises when Kadek Sumerti has to take part in a tooth-filing ceremony at her parents' home. Because marrying into a brahmana family has raised her status, she is only allowed to attend the ceremony on condition that her family provide her with a special platform, higher than that used by her brothers and sisters. Kadek Sumerti's parents reject this condition because they still consider their daughter to be of their status, particularly in the context of the tooth-filing ceremony, which is the responsibility of the birth family. Kadek Sumerti faces the dilemma of whether to follow the wishes of her husband or her parents, but she knows that taking either path will arouse opposition from the other party. Her husband threatens her with divorce if she obeys her parents' wishes. Finally, Kadek Sumerti decides not to participate in the ceremony, but comes to her parents' house just to watch. The pain that this conflict has caused is expressed as follows: 'Kadek Sumerti's eyes were full of tears, her breast was as though pressed between two pieces of iron as cold as ice, and her mind was flying far away behind the palace walls. Did they realize her

27 'The palace wall'. This story was first published in Kompas 3-12-1993. It was included in Aryantha Soethama's short story collection Mandi api (2006). For its English translation, see Lingard 1995:12-9. 
heart was in agony, as though it had been sliced by a blade of split bamboo?'28

The sad ending of this story provides a strong message about the discriminatory impacts of the caste system, something that modern Balinese writers oppose because they support the principles of equality and modernity. In another story titled Bohong (Lies, 1994), Aryantha Soethama uses an explicit rejection of discrimination based on caste status as his theme. Compared to the previous story, this one contains a clear, direct critique of the caste system and adat practices used to maintain the social hierarchy. Bohong ${ }^{29}$ tells the story of Sagung Mirah, a distressed triwangsa bride, before her wedding ceremony with a jaba husband. Her father insists that unless a patiwangi offering takes place, he will not permit the wedding to proceed, while her father-in-law sees the request as a humiliation and therefore refuses to do it. To ensure the patiwang $i$ is provided, Sagung Mirah's father sends his female servant to witness the ritual. To this witness, Sagung Mirah insists: 'My husband's family will not provide patiwangi. They do not want their self-respect to be belittled.' ${ }^{30}$ As in the stories discussed above, here again, it is the bride rather than the groom who faces the difficulties in an intercaste marriage. During this mediated dispute between the two sets of parents, Sagung Mirah takes the side of her father-in-law and asks the witness to lie by saying that the patiwangi offering has been provided and that the wedding ceremony has proceeded smoothly. This story tries to explain that patiwangi is not obligatory and that triwangsa may manipulate it to protect their status and all their assumed caste privileges. In order to strengthen this point, the narrator creates an authoritative figure, a priest, who in fact does not ask at all about patiwangi during the wedding ritual. Unlike Tarian bumi where a long overdue patiwangi besi sedingin es, dan pikirannya menerawang jauh ke balik tembok puri. Adakah mereka tahu hatinya yang perih seperti diiris-iris sembilu? (Soethama 2006.)The English translation is taken, with minor revisions, from Lingard 1995:19.

29 The story is included in Aryantha Soethama's short story collection Mandi api (2006:80-5).

30 Keluarga suamiku tak akan menyediakan patiwangi. Mereka tak ingin martabat mereka direndahkan. (Soethama 2006:83.) 
ritual is performed, in this story it is explicitly rejected with a combination of ridiculous lies and trustworthy arguments from the priest. But, the different ways in which Balinese writers deal with the issue of patiwangi should be seen as a reflection of the absence of uniformity in Balinese society in dealing with the practice of adat. What is certain is that their stories illustrate the inability of Balinese to detach themselves from adat and that that consequently hinders and thwarts their adoption of a modern identity.

\section{The caste system and false identity}

One important principle of the caste system is that status is defined by birth, with caste descending through the paternal line. The offspring of brahmana must have the same status as their parents, and similarly children of jaba parents will automatically be commoners. But, when children who were born out of wedlock are involved, identity becomes a complex question: should they be granted the status of the biological father, the mother or the nurturing family? Writers who tackle this aspect of caste are Putu Wijaya in the novel Bila malam bertambah malam (As night grows darker, 1971), Ngurah Parsua in the novel Sembilu dalam taman (Grief in the park, 1986) and Oka Rusmini in the short story Sagra (1998) and her novel Gurat-gurat. ${ }^{31}$ Although these three writers are triwangsa, they use their writing to promote the importance of equality and humanity. In their work, they approach caste status as either a false or an inconsequential way of defining identity. Their concern is not whether a true identity is necessary but rather, if caste status can be false, why should efforts be made to rigorously maintain it.

Bila malam bertambah malam tells the story of a hypocritical triwangsa woman who marries a man of the same rank while continuing a love affair with the commoner servant she has refused to marry because

31 'Scratches', Rusmini 2003c. This novel was originally serialized in the Bali Post in 1996. After some revisions, including the names of characters, it was republished in serial form in the newspaper Koran Tempo in 2002, and then published as a book by Grasindo with the title Kenanga (Rusmini 2003). This analysis is based on the serial published by Bali Post. 
of caste difference. The woman, Gusti Biang and her husband I Gusti Ketut Mantri, have a son called Ngurah. According to caste theory, Ngurah's status is triwangsa, the same as his parents. Towards the end of the novel, however, it is disclosed that Ngurah's father, Gusti Ketut, who was killed in the revolution, was in fact impotent. The question then arises - who is really Ngurah's biological father? Gusti Biang's servant and former lover, Wayan Tua, gives the answer directly to Ngurah.

'He [Gusti Ketut Mantri] had fifteen wives', Wayan continued, 'but that was only to cover up his impotence. When he had to perform his duties as a husband, I was the one who did most of that. But this was kept secret, until, until...', the old man said nervously, 'until y-y-you... were born, Ngurah, and considered him to be your real father. Why don't you ask your mother who your real father actually is?'32

Living in the same house as a servant enables Wayan Tua and Gusti Biang, who actually still love each other, to establish a sexual relationship, which continues until after Gusti Ketut Mantri is killed during the revolution. Wayan Tua reveals that he himself shot Gusti Ketut Mantri because he spied for the Dutch and leaked plans to them, causing the deaths of dozens of members of the Balinese guerrilla movement. For Wayan Tua, killing Gusti Ketut serves the dual function of removing a traitor to the revolution, and reopening the path to his lover. The depiction of a triwangsa as a traitor and sexually powerless clearly demonstrates the author's intention of undermining the stereotypical image of the nobility of the upper caste. Comparisons can be made here with traditional literature, in which members of the ksatria caste were expected to combine military, political and sexual prowess.

Caste conflict occurs between Gusti Biang and her son Ngurah,

32 'Dia memiliki lima belas orang istri', kata Wayan melanjutkan, 'tapi itu hanya untuk menutupi kewangduannya. Kalau dia harus melakukan tugasnya sebagai suami, tianglah yang sebahagian besar melakukannya. Tetapi itu tetap menjadi rahasia, sampai, sampai...,' kata orang tua itu dengan gugup, 'sampai kkkk-ka-kakau lahir, Ngurah, dan menganggap dia sebagai Ayahmu yang sebenarnya. Coba tanyakan kepada Ibu Ngurah, siapa sebenarnya Ayah Ngurah yang sejati.' (Putu Wijaya 1971:103.) 
particularly when Ngurah tells his mother that he is going to marry Nyoman Niti, Gusti Biang's maid. Portrayed as a stereotypical narrowminded triwangsa, Gusti Biang rejects Ngurah's marriage plans. Like most upper-caste people who prefer endogamous marriage, Gusti Biang wants Ngurah to marry a woman of the same rank and has already chosen someone for him. As an educated person, Ngurah, who has studied in Yogyakarta for five years, defends his freedom to choose and affirms that he will marry his girlfriend, regardless of her rank. Once again the author uses leaving Bali as a means of resolving an argument over caste differences, a device used in several stories discussed above. Gusti Biang, who is depicted as an arrogant triwangsa, threatens her son: 'If you really want that commoner woman to satisfy your lust, well, it's up to you. You can keep her as your concubine. You can do whatever you like to her, because I have looked after her since she was a little girl. But marry her in a ceremony - you can't do that!'33 At this point, the dispute between Gusti Biang and her son can be reduced to the kind of intergenerational conflict already discussed. But in Bila malam bertambah malam being old does not necessarily equate with being conservative. At the height of the argument, the author imposes an authorial voice through the figure of Wayan Tua (Tua literally means 'old' or 'adult'). He urges Gusti Biang to forget her concerns about caste and permit Ngurah to marry. He says: 'We have already suffered enough because of caste' and reminds her that 'now the world has changed'. Finally, Gusti Biang accepts Wayan Tua's reasoning and gives permission for Ngurah to marry Nyoman Niti, but the novel ends without the marriage having taken place. It is not the aim of the novel to go further and explore the consequences of intercaste marriage, but to make the point that caste status is illusory and irrelevant to the modern world.

In Ngurah Parsua's novel Sembilu dalam taman (1986), the fate of a child born outside of marriage is the source of caste conflict between a triwangsa father and his son. The father prevents his son, Gusti Made

33 Kalau kau ingin juga kepada perempuan sudra itu karena nafsumu, itu terserahlah. Kau boleh memeliharanya sebagai selir. Kau boleh berbuat sesukamu terhadap dia, sebab aku telah memeliharanya sejak kecil. Tetapi untuk mengawininya dengan upacara, itu tidak bisa! (Putu Wijaya 1971:83). 
Lodra, from adopting his biological child born to a commoner. Gusti Lodra is an anthropology student who meets and falls in love with Suastini while doing fieldwork in her village in North Bali. Suastini becomes pregnant by him, but he is unable to marry her because he has to continue his studies in Jakarta, another example of the way youth and modern education are used by Balinese writers to justify opposition to caste and other irrelevant traditional values in recent times. In Balinese society it is unacceptable for a woman to have a baby without a husband, so an arrangement is made for Otar, a villager whose life Lodra has saved in a fight, to marry Suastini. After completing his studies, Lodra visits the couple and expresses his willingness to adopt the child who will be born to Suastini. The couple agrees, but Lodra's commitment is strongly rejected by his father: "'Don't be crazy. The community here will laugh when they see what you're doing. We are descendants of real ksatria. Our ancestors were once great kings. Don't disgrace them with this", his father said sternly.'34 Using exactly the same line of argument, Lodra counters his father: "'But then wouldn't it mean that I have sinned by abandoning my ancestors, whose spirit lives in the child? So, will our ancestors return to life in a commoner?" Lodra asked.' 35 The birth does not take place until the end of the story and the matter of the child's status remains unresolved. In the meantime, the disagreement between Lodra and his parents touches on several aspects of caste identity and descent. In the conflict, the father is portrayed as belonging to an oldfashioned generation, proud of his caste status but lacking humanity, while the son is shown as a young educated person who believes that adat should be abolished because it violates humanity.

Humanity is linked to the traits of good personality, behaviour and budi (character), which Lodra considers more important than birth or descent in defining status. This emphasis on budi in Sembilu dalam taman indicates that the ideas disseminated by Surya Kanta

34 'Jangan gila! Masyarakat di sini akan tertawa melihat perbuatan itu. Kita adalah keturunan ksatria asli. Leluhur kita pernah menjadi raja-raja besar. Jangan nodai dengan perbuatan itu,' kata ayahnya keras. (Parsua 1986:129-30.)

35 'Bukankah berarti saya telah berdosa menelantarkan leluhur saya yang menjiwai anak itu. Jadi, leluhur kita akan lahir sebagai seorang sudra?' tanya Lodra. (Parsua 1986:129.) 
when they opposed the caste system in the 1920s continued to be relevant and unresolved in the 1980s. In both Ngurah Parsua's and Putu Wijaya's novels, the rejection of status defined by birth or descent is explained through interesting examples of children born from adulterous relationships.

A more complex view of the caste identity of a child born out of wedlock and her relationship with her biological parents is presented in two works of Oka Rusmini, Gurat-gurat and Sagra. While the subject matter of these works is complex, this intricacy is also partly a result of the generally increased sophistication of fiction writing in Indonesian in the 1990s. In the novel Gurat-gurat, Ida Ayu Jingga, a brahmana woman, engages in an unusual relationship with her maid and daughter, Intan, and her former lover, a brahmana doctor, Ida Bagus Palguna. Dayu Jingga and Palguna love each other but decide not to marry. Instead, Dayu Jingga's family arranges a marriage between Palguna and Dayu Jingga's sister, Dayu Bulan. Dayu Jingga remains unmarried and develops a career as a university lecturer while continuing her relationship with Palguna. While she is in Yogya undertaking postgraduate study, Dayu Jingga gives birth to a baby fathered by Palguna and asks a local family to look after her. It is socially unacceptable for a woman to give birth without a husband in Bali and when that happens it causes great shame to her family. In this novel, the author has deliberately chosen a place outside Bali for Dayu Jingga to give birth secretively so that her family and community in Bali hardly know about it. Moreover, it makes it possible for Dayu Jingga to ignore caste principles; for example, she does not add an appropriate caste title to her daughter's name, Intan. After some years, she employs her daughter, as her maid. Intan does not know the truth about her birth, but feels that Dayu Jingga loves her as a real mother would.

The relationship between the 'employer' Dayu Jingga and 'the orphan maid' Intan provides opportunities for Intan to search for her identity. Dayu Jingga tries to reveal her relationship to Intan gradually and carefully in a way that avoids hurting either her own feelings or Intan's. In reality, Intan has commoner status and never imagines having brahmana parents. Nevertheless, despite being a commoner, Intan possesses all the presumed brahmana character traits - she is 
beautiful, wise and bright. Psychologically and physically, Intan is depicted as a true brahmana, but socially, her caste is jaba. The process of achieving her 'true' caste, by becoming a brahmana woman, is very complicated. When Dayu Jingga gives Intan a tusuk konde, which implies that she is indirectly acknowledging her daughter, and that Intan's status is equal to her own, Intan does not take this to mean that Dayu Jingga is her biological mother - this realization only comes at the end of the story. In this story, as in Tarian bumi, Oka Rusmini again interestingly uses the motif of passing on a tusuk konde to emphasize the special relationship between mother and daughter.

Oka Rusmini's Sagra highlights even more detailed and alarming images of the brahmana attitude toward extramarital affairs than those that occur in her other works or in those by Putu Wijaya and Ngurah Parsua. As a woman, Oka Rusmini offers a female insider's view of the problem. Sagra describes a situation in which a brahmana couple, Ida Bagus Baskara and Ida Ayu Pidada, and a commoner couple, Jegog and Sewir, exchange partners. The story is told from the point of view of Sagra, the daughter of Jegog and Sewir. Sagra has a similar life history to Intan, surrounded by identity mysteries that she wants to solve. Although giving an important emphasis to the universal theme of life as a great mystery or puzzle, ${ }^{36}$ both works present an image of triwangsa behaviour as arrogant and selfish throughout the stories.

As the story unfolds, Sagra reveals that her 'official' father and mother - Jegog and Sewir - have each been involved sexually with the brahmana husband and wife, Baskara and Dayu Pidada. Sagra was born as a result of the affair between Baskara and Sewir, who works as a maid in Dayu Pidada's geria, while Dayu Pidada and Jegog have produced a daughter, Ida Ayu Cemeti. Sagra must have brahmana blood because her biological father is a brahmana, while in contrast, Cemeti's brahmana status is questionable because despite being born

36 In Sagra, a character says to Sagra that 'Sagra, hidup ini adalah tumpukan rahasia. Bila kau mampu memecahkan rahasia itu, bukan hidup lagi namanya! (Sagra, this life is a great mystery. If you could overcome that mystery, it is no longer called a life) (Rusmini 2001). In Gurat-gurat or Kenanga, two of the main characters say: 'Rasanya hidup ini seperti teka-teki yang tak ada habisnya [...]' / 'Dan kita bagiannya'. (Rusmini 2003a:292.) ('This life feels like a never ending puzzle[...]' / 'And we are part of it.'). 
from a brahmana mother, her biological father is a commoner. In a revealing statement, Dayu Pidada confesses that she has 'anointed her daughter with fake nobility'. ${ }^{37}$ She also confesses that she has lied to her family members, and that her marriage to a brahmana man (Ida Bagus Baskara) was simply a ruse to enable her baby to have a brahmana title. Both male characters, Baskara and Jegog, die mysteriously as if they have been cursed for what they have done. This is another example of the belief in panes. In a reflective mood, Dayu Pidada acknowledges the secret sexual affairs between herself and Jegog and between her husband and Sewir in the following declaration:

'I have paid for all your misfortune, Jegog. Luh Sagra, the girl who was born from an affair between your wife and my husband, is with me now. I knew she was the one who was actually a noble woman. Our daughter, Cemeti has died, Jegog.' ${ }^{38}$

Here Dayu Pidada makes it clear that she is aware of the false caste identities of both Sagra, who should be a brahmana, and Cemeti, who is in fact a commoner. However nothing at all will change because she keeps these matters secret to protect the dignity of her own status and that of her extended family members. Dayu Pidada is a yet another modern, educated person who has studied business in Boston and made business trips to places including Japan, France, Germany and America. But unlike the other educated characters discussed above who oppose caste hierarchy, Dayu Pidada's attitude to caste status is very traditional. Not wanting to hurt her family by marrying the commoner lover who has made her pregnant, she instead marries a brahmana man chosen for her by her mother. By marrying a brahmana, she ensures her child will have the same status as her husband. In the stories already discussed, central characters, including Ngurah in Bila malam bertambah malam, the unnamed son of Gusti Lodra in Sembilu dalam taman and Sagra and Dayu Sewir in Sagra, all have false caste identities. However, these stories do not establish that status should rightfully be allotted according to birth;

\footnotetext{
37 Telah mengoleskan kebangsawanan palsu. (Rusmini 2001:196-7.)

38 Sudah kubayar seluruh kesialanmu, Jegog. Luh Sagra, anak hasil hubungan gelap istrimu, Luh Sewir, dengan suamiku, sekarang bersamaku. Kutahu dialah yang sesungguhnya seorang bangsawan. Anak kita Cemeti telah mati, Jegog. (Rusmini 2001:197.)
} 
they show instead that the seemingly inviolable caste system can, in fact, always be manipulated. The basic principles of the caste system are made to look ridiculous in these stories.

Another story that makes a mockery of the principles of the caste system is Aryantha Soethama's Sekarang dia bangsawan (He is an aristocrat now, 1996). It tells the story of a poor jaba farmer who, after becoming a successful businessman in the tourism industry, raises his rank to triwangsa. He changes his name from I Ketut Linggih by adding an appropriate triwangsa title and becomes Gusti Agung Linggih. His splendid house is no longer called a 'house', but a puri or palace. Through a character who is one of Linggih's employees, the narrator shows that Linggih can lift his status to whatever level he wishes because he is rich. In his study on status mobility in Bali, Leo Howe (1995) mentions wealth as one of the motivating factors, and this story shows caste status as something that can be purchased, not an identity ascribed by birth. Sekarang dia bangsawan, along with the stories discussed previously, ridicules and treats with cynicism the rigid principle of caste-based identity. Rather than offer solutions which could promote equality, Balinese writers simply generate negative depictions of the caste system which illustrate how Balinese struggle with traditional concepts of identity.

\section{Caste conflict and issues of gender}

This analysis highlights the dominant role allocated to female characters in the conflicts arising from intercaste marriage. In intercaste marriages, women suffer more than men, regardless of their caste status. This relates to the fact that women are always required to reconfigure their identities in intercaste marriages, while the identity of men is not threatened or altered. Women with upper-caste status, for example, risk being disowned by their parents or made unwelcome by members of their husbands' families. The mothers-in-law of Dayu Telaga in Tarian bumi and Dayu Ratih in Putu menolong Tuhan even accuse them of being agents of misfortune. Similarly, commoners who marry up face discrimination as second-class triwangsa from members of their husbands' families and also face dilemmas when 
they have to attend religious rituals or traditional ceremonies in their original homes because they are prohibited from mixing with their own family members. Jero Kenanga in Tarian bumi is not allowed to pray in her family temple, meaning that her spiritual contact with her ancestors is broken. Likewise, Kadek Sumerti fails to participate in an overdue tooth-filing ceremony, an essential element of the life cycle rituals for Balinese, which should be carried out before marriage. The caste system strongly underpins gender inequality and opposition to this is what the writers want to highlight through the female characters in their stories.

As opposed to the generally accepted images of Balinese women as powerless and submissive, in these stories the women whose lives are rendered miserable because of the restrictions and discrimination imposed on them by caste are portrayed as assertive figures. Their criticism of the unfairness of the caste system is depicted as brave, while male characters support them in the background. In Kesetiaan perempuan, Mega hitam pulau khayangan, Hunus and Tarian bumi uppercaste women strongly criticize the suffering that they have had to endure because of the negative impact of the caste system on their lives, using different arguments such as status discrimination, gender inequality, their lack of freedom and the burden of adat. Because they have their own aspirations as young, educated people expecting a spirit of freedom, these women leave behind their caste status with no regret and are ready to face any consequential risks. Perhaps a major reason that Balinese writers frequently articulate their anti-caste feelings through female characters is that women are the major victims of caste discrimination and therefore it is more sensible and convincing for them to voice opposition to it, but there are also examples where caste differences are well displayed through the sufferings of male characters.

Female characters are also important because they are the bearers of the spirit of modernity in that they are depicted as educated people who have a strong preference for modernity, equality and freedom. Agung Ari in Hunus and Dayu Sumartini in Mega hitam pulau khayangan are both university students who continue their education in Jakarta. Dayu Jingga in Gurat-gurat and Dayu Ratih in Putu menolong Tuhan are lecturers. Their educated background allows 
them to oppose traditional values and to support their arguments with discourses on modernity. Dayu Sumartini uses the metaphor of equating the caste system to a badly fitting traditional costume, implying the need to discard a way of life which is no longer relevant. Dayu Telaga protests radically that she never expected to be born a brahmana and rejects the identity allotted to her at birth, while Dayu Sumartini makes a similar complaint and displays a preference for being a commoner:

'Why did I have to be born as Ida Ayu Ketut Sumartini? Why not just as Ketut Sumartini? Why must I bear the title Ida Ayu? Why?'39

Gung Ari in Hunus expresses her dismay at caste restrictions by drawing on the figure of the Indonesian feminist, Raden Ajeng Kartini (1879-1904) who fought for female emancipation but sadly, finally accepted an arranged marriage organized by her parents. Gung Ari reflects:

'Kartini had long gone, but have I become her successor? Indeed I have been given education to tertiary level and stayed in the capital city, but I have never enjoyed the freedom I expected. ${ }^{\prime 4}$

While Kartini lived long ago, she is still regularly used as a point of reference, although she is sometimes parodied rather than used in a positive context, as in this story and others discussed in Chapter VI. Like other female characters whose wish to marry down has been opposed, Gung Ari also makes her own decision. She takes advantage of the modern options available, which are quite different from the late nineteenth-century values Kartini faced, and ignores her parents' desire for her to marry a person of the same caste. She chooses elopement instead, abandoning her caste with pride, as a young modern educated woman. Her decisive attitudes and the courage she shares with other female characters in the stories are examples of progressive ideas on the long path of struggle to social and gender equality within Balinese culture.

39 Mengapa aku harus lahir sebagai Ida Ayu Ketut Sumartini? Mengapa tidak sebagai Ketut Sumartini saja? Mengapa harus pakai Ida Ayu? Mengapa? (See Sukanta 1978.)

$40 \quad$ Kartini telah lama pergi, tetapi, apakah aku sudah menjadi penerusnya? Memang aku telah disekolahkan sampai ke perguruan tinggi, tinggal di ibu kota, tetapi aku tidak pernah menikmati kebebasan yang kuhendaki. (Basuki 1994:180) 
As noted in Chapter III, the struggle against the caste system began as early as the 1920s and continues until the present. Endeavours to remove the caste system have always been matched by those fighting to maintain it. Amidst strong attacks on the caste system and the social hierarchy, there has been one unusual phenomenon: namely that of both jaba and triwangsa wishing to raise their status. In his study on this phenomenon, Howe (1995:41) has aptly argued that the preoccupation with status and hierarchy was and is in no sense limited to the triwangsa, but is instead pervasive throughout all levels of Balinese society'. Social hierarchy is universal and a part of every society. In Bali, however, it is predominantly defined by, among all other factors, the caste system. The caste system and the social inequality that it perpetuates continue to be a site of status struggle and symbolize the ambivalence of contemporary Bali. Many social conflicts in Bali that were exposed by the local mass media have actually been triggered by caste difference (P. Wirata 2007). These social conflicts are often named caste conflict. The literary works discussed here can be seen as part of the ongoing phenomena of caste conflicts and status inequality.

The stories are written by writers from both triwangsa and jaba backgrounds. Their personal caste status, however, really does not seem to determine the position they take against the caste system. Putu Wijaya, Ngurah Parsua and Oka Rusmini are all triwangsa, but along with their jaba counterparts such as Rasta Sindhu, Putu Oka Sukata, and Aryantha Soethama, they overtly criticize the caste system. Instead of showing a preference for the caste-based social hierarchy in which they as triwangsa are placed at a higher level, these upper-caste writers, through their works, instead support the idea of social equality and propose the removal of the caste system. The works of upper-caste writers consistently describe how the caste system discriminates between human beings at birth and show that it works against a state of equality and modernity. By continuously showing the dark side of the caste system Balinese writers, regardless of their rank, demonstrate antipathy to it. Instead of exhibiting pride in their traditional status and the adat practices that perpetuate it, Balinese writers show a strong preference for the humanity and equality that make up a modern identity. 